\title{
Przyszłość w nowoczesnym projektowaniu miast
}

\section{The future in modern city design}

\section{Streszczenie}

Zmiana w postrzeganiu przestrzeni urbanistycznej prowadzi do konieczności tworzenia nowych opracowań prawnych, własnościowych, zabezpieczeń, kodyfikacji i komunikacji, również porozumień międzynarodowych, wymiany danych, wspólnych badań, dopełniających opracowań itp. wszystkich o zasięgu globalnym, kompatybilnych i powszechnie zrozumiałych. Są one niezbędne do osiągnięcia globalnej równowagi środowiskowej i przywrócenia warunków życia.

Słowa kluczowe: lokalność i globalizacja, współpraca naukowa i społecznościowa, uświadomienie społeczne, porządek prawny

\begin{abstract}
Changes in the perception of the urban space leads to the need to create (global scope, compatible and universally understood) new legal, proprietary, security, codification and conduct communication studies, including international agreements, data exchange, joint research, complementary studies, etc. There is a necessity to achieve global environmental sustainability and restore living conditions.
\end{abstract}

Keywords: locality and globalisation, scientific and social cooperation, social awareness, legal order 
Jako odpowiedzialni mieszkańcy Ziemi chcemy zapewnić najbliższym i dalszym pokoleniom niezmienione warunki ziemskiej egzystencji i przekazać zrozumiałe wartości kultury, którą tworzyła wiekowa tradycja. Temu też ma służyć łączność internetowa - przenoszenie informacji, które jest warunkiem uświadomienia, wiedzy i współdziałania całej ludzkości. Aktywiści światowi planują do 2020 roku wypełnić cały świat siecią internetową w celu stworzenia stałego połączenia i nieprzerwanej wymiany informacji. Wspólnota i porozumienie powinno dotyczyć nie tylko sfery komunikacyjnej, podobnie symbiotycznie powinny działać przemysły nie tylko różnych krajów, ale też różnych gałęzi, wspomagając się wzajemnie zarówno energią, jak i kolejnymi stadiami produkcji dóbr, które z kolei mogą być transportowane i przesyłane bezpiecznymi korytarzami podziemnymi, łatwiej i szybciej niż tradycyjnie na powierzchni, a do tego bezkolizyjnie. Według H. Brown globalna sieć tuneli zaopatrzona będzie we wszystkie frakcje obsługi, od światłowodów łączności i szybkiego Internetu przez wieloużytkowe rury instalacyjne, systemy dystryktów grzewczych logistykę dystrybucji różnych systemów aż po szybki transport. Bazą zmian musi być perspektywa całościowego systemu przemysłowego ${ }^{1}$. Rozwój takiej „industrialnej symbiozy” wymaga przede wszystkim przestawienia sposobu myślenia z produkcyjno-konsumpcyjnego na proekologiczny. Ale też wielkiego wyboru nie mamy, jeśli chcemy przeżyć.

\section{PRZEŻYĆ - TO WARUNEK}

Warunkiem przeżycia jest budowanie zrównoważonych miast i zrównoważonych społeczności. Temu poświęcona była Habitat III - konferencja w Quito w Ekwadorze w 2016 roku. Kampanię zainicjowaną przez powołane tam Generalne Zgromadzenie Partnerskie ukoronował raport The Cities We Need: Towards a New Urban Paradigm (Miasta jakich potrzebujemy: ku nowemu paradygmatowi urbanistycznemu). Raport ten ujmuje podziemie jako znaczącą sferę działania dla zmiany paradygmatu. Założony termin osiągnięcia stanu zrównoważenia dla dużych miast globalnych wyznaczono na rok 2030.

Czy to daleki termin? Stanowczo nie jest daleki, zwłaszcza jeżeli walczy się z opóźnieniem w stosunku do reszty świata. Bezwzględnie jednak należy do tej pory wyrównać globalne różnice i:

1. wzmocnić elastyczność, zwiększyć zdolność adaptacyjną i pojemność rezerwuarów na wypadek każdej anomalii klimatycznej - we wszystkich krajach i miastach,

2. zintegrować pomiary zmian klimatycznych, uwzględniając je w prawie narodowym, strategii i planowaniu,

3. edukować - zwracając szczególną uwagę na zmiany klimatu, podnosząc humanistyczny wymiar tych zjawisk i wzmacniając instytucjonalne działania w celu powstrzymywania zmian, adaptacji do nowych warunków, redukcji dotkliwości tych zmian oraz w celu wczesnego ostrzegania. 
Duże miasta już od dawna walczą z przeciwnościami klimatycznymi, zabezpieczając się np. przed wodą powodziową wyniszczającą regularnie dobytek mieszkańców i zasoby miejskie, tworząc zbiorniki o dużej pojemności. Dla przykładu w Tokio zbudowano w latach od 1992 do 2006 ogromny metalowy rezerwuar podziemny „The Temple” (25,4 x 177 x 78 m) z 59 gigantycznymi słupami podtrzymującymi konstrukcję, do którego spływają nadwyżki wód z kanałów i tuneli. Malezja może się poszczycić eksperymentalnym smart tunelem komunikacyjnym w Kuala Lumpur, który na co dzień służy jak standardowy dwupoziomowy tunel komunikacyjny - fragment obwodnicy miasta, ale gdy w porze deszczowej zaczynają podnosić się wody rzek dopływów, które dotąd pustoszyły stolicę, basen górny kieruje nadmiar wód do tunelu, sukcesywnie go wypełniając, równocześnie wygaszając ruch samochodowy - kolejno najpierw dolny, później górny poziom aż do wypełnienia zbiornika tunelu. Dolny basen (cały tunel ma profil obniżający się na południe miasta wraz z kierunkiem spływu rzek) wraz ze śluzą u wylotu zbiornika regulują powolny systematyczny odpływ wód aż do opróżnienia tunelu i przywrócenia ruchu samochodów. Jeszcze innym przykładem może być Rotterdam - miasto posiada duży zbiornik wód powodziowych pod ogromnym miejskim parkingiem. Generalnie podziemia dużych miast wykorzystywane są z powodzeniem do zabezpieczania przed katastrofami klimatycznymi.

Pod ziemię również wpompowywany jest dwutlenek węgla - w pustki po wyrobiskach mineralnych. Wykorzystanie tych zasobów gazu jest wciąż nierozstrzygnięte, ale planuje się m.in. zastosować je jako paliwo (wodorowe) do samochodów. Odkrywczość i pomysłowość ludzi zainteresowanych postępem w kierunku poprawy krytycznej sytuacji klimatycznej są ogromne. Potrzebna jest jednak współpraca organów państwowych, aby nadać bieg wdrożeniom, ale najważniejszymi zadaniami są wprowadzenie założeń nowego paradygmatu urbanistycznego w planowanie urbanistyczne i nakłonienie wszystkich decydentów do proekologicznego, w pełni świadomego, nowoczesnego myślenia.

Oczywiście planowanie przestrzenne im bardziej wielokierunkowo przebiega (3D), tym więcej problemów dotyczących wzajemnych współzależności funkcjonalno-użytkowych ze sobą niesie. Mając na myśli projektowanie miasta w głąb ziemi, mówimy o konieczności całościowego przebadania układu geologicznego terenu miejskiego. Bez znajomości problematyki tunelowania i pełnego serwisu o składzie i układzie warstw skorupy Ziemi nie jesteśmy w stanie odpowiedzieć wiążąco na problem możliwości budowlanych podziemia.

\section{DZIAŁANIA NA RZECZ ZRÓWNOWAŻONEGO ROZWOJU}

Rząd holenderski i jego Narodowy Wydział Planowania wydał w 2001 roku publikację pt. Eksploracje przestrzenne 2000. Doniosłość dobrego podziemia (RPD 2000). Poza dokumentacją dotyczącą geologii terenu kraju i przedstawienia sposobów jego eksploracji najdonioślejszą wartością była zmiana w sposobie myślenia o planowaniu urbanistycznym, które od tej pory przebiegało zawsze trójwymiarowo (3D) i w trzech głównych kategoriach warstw: 
1. mieszkalnictwo,

2. sieci infrastruktury,

3. podziemie.

Przyjęto odtąd jako obowiązującą taką właśnie warstwową metodę analiz planistycznych ${ }^{2}$. Wszelkiego rodzaju analizy urbanistyczne dotyczące miasta przebiegają na podstawie układów warstwowych i z uwzględnieniem analizy geologicznej podłoża. Warstwą najbardziej stabilną użytkowo okazuje się podziemie.

Zmiany w systemach wodnych i biotycznych mierzy się na stulecia. Infrastruktura i zmiany na powierzchni następują znacznie szybciej - ok. 40-60 lat. To jest okres wymiany struktury przyziemia. Na powierzchni, która obejmuje podstawowe czynności życiowe, jak mieszkanie, praca i rekreacja, czas zmian to jedno pokolenie, 10-30 lat. Rządowy raport opracowany metodą analizy urbanistycznej wskazuje strefę eksploracji podziemia jako bezpośrednio powiązaną i eksploatowaną z poziomu mieszkalnego i poniższej warstwy sieci. Odtąd pomiary w analizach urbanistycznych wykonywane są trójwymiarowo (długość, szerokość, głębokość i wysokość). Odtąd też podziemie analizuje się z dwóch różnych perspektyw: jako rezerwuar przestrzeni podziemnych i jako kompleks różnych ekosystemów (rodzaj gruntu, wody gruntowe, systemy biologiczne). Uwaga ekologów i konserwacjonistów zwraca się teraz ku podziemiu. Zmuszeni są obecnie do obserwacji zagrożeń ekologicznych również w warstwach dotąd nienarażanych nadmiernie na zniszczenia. $W$ tym kontekście jest na przykład rozważany ww. problem przechowywania wpompowanego pod ziemię dwutlenku węgla. Mówiąc więc o zrównoważonym rozwoju, musimy określić wielkości graniczne ingerencji podziemnych i narzucić normy wskazujące możliwości ich wykorzystania oraz sposoby użycia.

W 2013 roku dwie badaczki Fransje Hooimeijer i Linda Maring (Uniwersytet Techniczny - Delft) opublikowały Projektowanie w podziemiu - publikację, w której podnoszą szczególną rolę projektów podziemnych:

1. w adaptacji zmian klimatycznych - kumulacja wody deszczowej i powodziowej w porach ekstremalnych - jako bazy dla zieleni miejskiej neutralizującej miejskie ciepło (wyspa ciepła),

2. w gospodarowaniu energią - wykorzystanie energii geotermalnej do ogrzewania oraz przechowywanie i składowanie energii naturalnej i pozyskanej,

3. stosowanie celowo zaplanowanych i wysokowydajnych smart rozwiązań - z pełną świadomością wysokich kosztów eksploracji i konstrukcji podziemnych.

De facto metoda analizy urbanistycznej stała się narzędziem projektanckim, a zasadnicza trójwarstwowa budowa objęła bardziej szczegółowy podział na kolejne warstwy praktycznych zadań projektowo-badawczych:

1. społeczność - ludzie - warstwa socjalna, humanistyczna,

2. metabolizm - żywotność i atrakcyjność miasta,

3. budynki - tkanka miejska,

4. przestrzeń publiczna - przestrzenie urbanistyczne,

5. infrastruktura i sfera podziemna. 
Kolejne uszczegółowienia w postrzeganiu i badaniach nad projektowaniem podziemnym przynoszą Maarten Hajer i Ton Dassen, publikując w 2014 roku wizję smart cities (miast inteligentnych) jako koniecznej przyszłości wszystkich skupisk urbanistycznych na Ziemi, gdyż metabolizm miejski pełni zasadniczą rolę w zachowaniu globalnej równowagi. Jest to wartość ukryta, więc jej uświadomienie wymaga szczególnego nacisku do ostrzeżenia przed globalnymi skutkami³. Po pierwsze należy uwolnić ludzkość od przekonania o dobrobycie płynącym z paliw kopalnych. Uświadomienie roli metabolizmu urbanistycznego oraz metabolizmu podziemnego - również niewidocznego dla projektanta - jest podstawą do projektowania smart, projektowania miast inteligentnych, czyli elastycznych, "sprytnych”, o optymalizowanym na bieżąco i na każdym kroku zużyciu.

Podstawową sprawą, którą należy uregulować, jest własność poszczególnych domen i stref przestrzennych. Jako główne można wyłonić: wodę, ziemię (grunty, podziały terenu), infrastrukturę i energię.

Kolejny podział dotyczy rozwarstwienia stosownie do głębokości występowania: płytkie podziemie, warstwa wodonośna i głębokie podziemie (powyżej 500 m). Przeprowadzone dotychczas próby zastosowania metody w praktyce już przyniosły pierwsze korzystne efekty (vide miasto Zwolle w Holandii lub Glasgow w Szkocji), a przeliczone korzyści w założeniu sukcesywnego egzekwowania planu powinny przynieść w perspektywie 25 lat efekt miasta spełniającego wszystkie cechy smart. Obecne efekty to $17 \%$ redukcja $\mathrm{CO}_{2}$ w powietrzu, oczyszczenie skażenia ziemi dające wartość $75 \%$ nowych areałów pod uprawy, zrównoważenie pokładów wodonośnych, zabezpieczenie przeciwpowodziowe, zabezpieczenie rezerw wody pitnej i czystych gruntów dla przyszłych pokoleń, zaopatrzenie w tańszą energię, woda i chłodzenie dla przemysłu. Oszczędności kosztów zużycia energii w przeliczeniu na docelowe 25 lat stosowania planu wynoszą $150 \mathrm{mln}$ euro. Spektakularna redukcja śladu węglowego (zniszczenia spowodowane stosowaniem pochodnych węgla i jego spalaniem) została uzyskana dzięki zakazowi używania węgla i odłączeniu gazu naturalnego jako podstawowego źródła energii grzewczej. W to miejsce wprowadzono ogrzewanie i chłodzenie domostw geotermicznie, z warstw wodonośnych Ziemi, oraz odkażanie gruntu jako warstwy przesiąkliwej pośredniczącej w wymianie wody z podziemiem ${ }^{4}$. W przeciągu 10 lat powinno nastąpić całkowite oczyszczenie gruntu z pozostałości węglowych.

\section{NOWOCZESNY PLAN ROZWOJU MIASTA}

Smart cities to miasta całkowicie odcięte od paliw kopalnych, oparte na świadomej partycypacji społecznej, nie tylko w użytkowaniu, ale i w planowaniu nowych inwestycji budowlanych. Naturalną koniecznością jest więc też włączenie w to planowanie pełnego zakresu problematyki podziemia miasta. Łącząc biofizyczną i socjalną domenę miast, nie sposób pominąć problemu metabolizmu miejskiego, którego procesy zachodzą właśnie 
w podziemiu. To życiodajna i zarazem najtrudniejsza, bo niewidoczna sfera życia miasta. Zależy więc całkowicie od poziomu świadomości społecznej.

Kolejnym, osobnym problemem wymagającym natychmiastowego podjęcia w działaniu jest uświadamianie samych urbanistów, których wiedza wyuczona w zakresach odnośnych gałęzi nauki składających się na poprawne funkcjonowanie miast (projektanci, architekci, planiści, geografowie, socjologowie, psychologowie, inni humaniści, artyści, ludzie kultury, aktywiści miejscy i wolontariusze, w końcu sami mieszkańcy) w tradycyjny sposób nie uwzględnia problemów podziemia. Konieczna jest szeroka interdyscyplinarna współpraca, aby osiągnąć widoczne efekty korzystne dla urbanistyki miast. Nie można też ominąć problemów kulturowych, jakie niesie w spadku historyczna przeszłość podziemia. Warstwy archeologiczne muszą być nie tylko uwzględnione i zabezpieczone, ale zinwentaryzowane w sposób trójwymiarowy. Podobnie jak całościowe myślenie i zapis urbanistyczny obejmujący przestrzeń miasta pojmowane muszą być trójwymiarowo (przestrzennie). Przestrzeń urbanistyczna miasta rozumiana jest dzisiaj jako obszar naziemny z odpowiadającą mu bez ograniczeń przestrzenią powyżej terenu i w głębi Ziemi. W powszechnym użyciu powinna to być „przestrzeń miasta”, już nie „obszar miasta”. Powinny być powszechnie dostępne dane nie tylko dotyczące powierzchni terenu, ale geologii, warstw wodonośnych, wód termalnych, klasyfikacji ziem, układu warstw gruntowych, dane historyczne, archeologiczne i inne. Ważne, aby te wszystkie dotychczasowe oraz nowo powstające dane podawane były w przestrzennych trzech wymiarach. Już nie jako „mapy” - a „modele” 3D. Tak, aby ich odczyty były kompatybilne, aby planowanie mogło przebiegać w jednoznaczny, niezakłócony sposób w przestrzeni urbanistycznej.

École Polytechnique Fédérale de Lausanne (Lozanna w Szwajcarii) opracowała Deep City Project - formę pośrednią modelu pomocnego w planowaniu miasta. Projekt polega na ramowej kompilacji danych podziemnych i naziemnych pozwalającej na ocenę możliwości użycia podziemia w relacji do potrzeb nadziemia. Jest to metoda dająca się łatwo stosować nawet w planowaniu operującym tradycyjnymi metodami.

Za ww. M. Hajerem i T. Dassenem (2014) należy niezwłocznie rozpoznać biofizyczną i socjalną domenę miasta, aby zrozumieć procesy jego metabolizmu. Należy w pełni ujawnić niebezpieczeństwa zagrażające miastu ze strony właścicieli gruntów, którzy na wzór „dzikiego zachodu" zechcą wykorzystać możliwości płynące z braku uregulowań dotyczących podziemia i uprawnień wynikających z własności naziemnej. Planujący przestrzeń muszą przejąć rolę pośredników dbających o dobrostan miasta, aby harmonijnie i w zrównoważony sposób mogło ono funkcjonować i rozwijać się.

Bezwzględnie jednak pełne uświadomienie sobie możliwości, a zarazem niebezpieczeństw płynących z braku wiedzy, jak również z niewłaściwego wykorzystania tego potencjału mogą i powinny doprowadzić do osiągnięcia równowagi. Organizacja Narodów Zjednoczonych doprowadziła do sprecyzowania 17 punktów SDG (UN Sustainable Development Goals). Osiągnięcie Celów Zrównoważonego Rozwoju wytyczonych przez ONZ założono do 
2030 roku, aby zahamować destrukcję klimatu i zapewnić wszystkim podstawowe warunki godnego życia w miastach na całym świecie. Cele te obejmują szeroki zakres wyzwań, takich jak zmniejszenie głodu, ubóstwa, zdrowie, edukację, równość płci, badanie zmian klimatu, zrównoważony rozwój miast, pokój i sprawiedliwość społeczna.

\section{WIZJA PROJEKTOWANIA MIAST}

W związku ze zmianami klimatycznymi miasta narażone są na działanie zjawisk pogodowych o takim nasileniu, jakiego nie spotykaliśmy wcześniej. Zjawiska te powodowane są pogłębiającymi się anomaliami klimatu, a to wszystko skutkuje coraz większymi klęskami żywiołowymi i stratami w ludziach jako bezpośrednich ofiarach oraz stratami majątku prywatnego i wspólnotowego. Aby zapobiegać katastrofom i minimalizować skutki takich zjawisk, miasta przyszłości powinny być projektowane elastycznie - w sposób dostosowujący je do zmian pogody i pozwalający stosownie i z wyprzedzeniem reagować na niebezpieczeństwa ${ }^{5}$.

Michael Bloomberg, wieloletni mer Nowego Jorku, znany filantrop, autor wielu rewolucyjnych akcji na rzecz mieszkańców NY, wraz z Carlem Pope'em, liderem weteranem ruchu ekologicznego, opisali w swojej bestselerowej książce Climate of Hope. How Cities, Businesses, and Citizens Can Save the Planet jak zabezpieczyć miasta przed kataklizmami, którymi mogą się stać niespodziewane nienaturalne skoki pogody, ale też np. cyberataki. Miasta, które są coraz większymi i coraz gęstszymi skupiskami ludzi, są narażone na zmasowane ataki, hekatomby, które zawsze celnie skierowane w tłum będą pociągać za sobą masowe ofiary i wyniszczające szkody. Zadaniem współczesnych mieszkańców miast jest coraz szybsze dostosowywanie się, równocześnie nadążając za przyspieszającymi stale zmianami w sposobach życia, dyktowanymi dynamizmem rozwoju cywilizacyjnego, a w razie katastrofy - szybsze odbudowywanie mienie i struktury miasta po zniszczeniach. Człowiek po każdej katastrofie, czerpiąc z doświadczenia strat, musi doprowadzić odbudowane dobra nie tylko do pełnego zabezpieczenia przed kolejnym takim zdarzeniem w przyszłości. Trzeba także dodać duży margines ochrony przed możliwymi jeszcze większymi zagrożeniami. Wskazówki podsuwają badania prowadzone zazwyczaj w kierunku przewidywanego rozwoju sytuacjí. Tylko pełna informacja, multidyscyplinarna wymiana zdań i społeczna współpraca mogą dać pożądane efekty. Tylko „miasta elastyczne”, czyli przygotowane mentalnie i organizacyjnie na potencjalny stres, są w stanie „odbić się” po ataku i uchronić przed traumą lub przynajmniej ją zminimalizować i zneutralizować.

W planowaniu zabezpieczeń przed nieprzewidzianymi atakami zmutowanej przyrody i rozchwianej aury w znaczący sposób może pomóc mądrze wykorzystane podziemie miasta. Wymaga ono jednak pełnego rozpoznania i zaplanowania eksploracji nie tylko zgodnie z legislacyjnymi prawidłami użytkowania (równoległego z naziemnym), ale z przewidywaniem wszelkich potencjalnych zmian ekologicznych. Nie można dopuścić na przykład do naruszenia 
równowagi między eksploatacją a ochroną biologiczną, co prowadziłoby do powstania tzw. brown fields, czyli gruntów zdegradowanych, które utraciły zdolność wegetacyjną. Ogromną rolę przypisywać należy cyrkulacji wody. Okresowe opady zwyczajowo wchłaniane są przez powierzchnie przepuszczalne, niezabudowane. Duże miasta jednak w wysokim stopniu są brukowane utwardzonymi nieprzepuszczalnymi powierzchniami (budynki, komunikacja jezdna, piesza), dzięki czemu zmieniają się podziemne układy wód w złożach, również w zależności od rodzaju naruszeń podziemia. Generalnie zmniejszona ilość wchłanianych opadów obniża poziom wód podskórnych, również sukcesywnie poziomów wodonośnych. To są skutki długofalowe, dające się zauważać po dłuższym czasie eksploatacji: wysuszają się tereny dotychczas wilgotne i podnosi się średnia temperatura. Tworzą się tzw. wyspy ciepła odpowiadające obszarom miast. Chłodzenie miasta, niedopuszczanie do przegrzewania, powinno stać się jednym z podstawowych zadań przywracania równowagi klimatycznej. Powoli istotnymi stają się (dzięki wysokim kosztom ogrzewania i próbom oszczędności energii cieplnej) szczelność i izolacyjność przegród budowlanych, zmniejszające emisję zewnętrzną i utratę ciepła wewnątrz budynków. Roczny balans wód opadowych zmienił proporcje z równomiernych drobnych opadów w ciągu całego roku na okresy suche i powodziowe. Podczas tych drugich ulewne burze tworzą w krótkim czasie ogromne ilości wody, którą trzeba przetrzymać w przygotowanych wcześniej zbiornikach lub sprytnie odprowadzić, aby zapobiec zalaniu miasta. Dzisiaj obawiamy się raczej niedostatku wody do chłodzenia, nawadniania, czystości - stąd niezbędna jest obecność zbiorników retencyjnych w miastach. Za zbiorniki retencyjne i podziemne rzeki odprowadzające nadmiary wód mogą służyć podziemne tunele komunikacyjne i parkingi. Jeśli są zaprojektowane z myślą o hybrydowej funkcji - jak malezyjski SMART Tunnel (The Stormwater Management and Road Tunnel) lub rotterdamski parking podziemny czy tokijski vast cavern, służą wielu celom, np. wprowadzają wodę do powtórnego użycia podczas nawadniania zieleni miejskiej, nawilżania i chłodzenia powietrza w mieście itp. Poprawie temperatury i jakości powietrza w mieście służą też korytarze powietrzne. Te ostatnie powinny być zaprojektowane konsekwentnie równolegle z myślą o huraganowych wiatrach, którym należy umożliwić przewiewanie bez oporu dodatkowych przegród budowlanych, których niefortunne usytuowanie naraża na dodatkowe straty. Tereny sejsmiczne z kolei chętnie korzystają z dobrodziejstw podziemia, ponieważ dodatkowo w głębi Ziemi mniej odczuwalne są drgania i mniej niebezpieczne wstrząsy.

Bez wątpienia ukształtowanie zabudowy to podstawa tworzenia jakości życia miejskiego i jego elastycznego reagowania na potrzeby chwili.

Niespodziewane rozpadliny osuwiska, upały powodujące zwiększone liczby zgonów, susze, sztormy i huragany, które dotykają coraz częściej nasze miasta, stają się powoli normą zmieniającego się klimatu. Wyspy ciepła i wody powodziowe to główne zagrożenia dla miast, będące efektem tych zmian klimatycznych. Trzeba przywrócić zieleń i wodę miastom, zmniejszyć ilość twardych nieprzesiąkliwych nawierzchni i absorbujących ciepło materiałów budowlanych. $\mathbf{W}$ jak największym stopniu należy pokryć zielenią i zielonymi 
dachami powierzchnie miastom i nawilżać je możliwie dużą ilością basenów i fontann, gromadzić nadmiar wód na cele sukcesywnej dystrybucji gospodarczej, zlikwidować monokultury, duże połacie upraw przemysłowych, przywrócić różnorodność biosystemów, zminimalizować ruch samochodowy na powierzchni, przepuścić gros komunikacji podziemnymi tunelami, ukryć pod ziemią parkujące samochody, oddać powierzchnię biologiczną Ziemi pieszym, faunie i florze, po prostu zabezpieczyć odnawianie się przyrody.

Żeby zabezpieczyć tę możliwość przyrodzie, musimy się sami nieco „usunąć”, ograniczyć naszą zachłanną ekspansywność i egoistyczną posesywność. Chcąc przy stale rosnącej liczbie mieszkańców miast zachować ich zamknięte - nie rozrastające się - obszary, a więc zachować ograniczenia powierzchniowe, a równocześnie utrzymać lub poprawiać proporcje obszarów zielonych i niebieskich w stosunku do szarych, zabudowanych, trzeba spiętrzać i dogęszczać tkanki istniejące lub właśnie można zagłębić się pod ziemię. Komunikacja wraz z infrastrukturą w oczywisty sposób już zostały zaanektowane przez podziemia miast, natomiast obecnie świat przekonuje się do zagłębiania miejskich funkcji usługowych na poziomy poniżej powierzchni. Powstają nie tylko podziemne place i galerie handlowe, ale całe podziemne miasta z pełną paletą usług i zapleczem gospodarczym. W wielu przypadkach zagłębione wnętrza urbanistyczne projektuje się tak, aby były otwarte, z pełnym dostępem powietrza i słońca, inne doświetla się częściowo lub pośrednio, zachowując potrzebny kontakt z otwartą przestrzenią i zielenią. Część wnętrz odpowiednio zaprojektowanych i wyposażonych może być całkowicie zamknięta, spełniając wszelkie wymogi dłuższego przebywania tam ludzi. To, co nas odstręcza od podziemi, to uwarunkowanie tradycją i strach. Klaustrofobia, która odwrotnie niż agorafobia, niepozwalająca dotkniętemu przypadłością wejść na skałę i spojrzeć w dół, nie pozwala nieprzyzwyczajonemu wejść np. do starej kopalni, chociaż tam odbywają się atrakcyjne koncerty czy spotkania. Wystarczy pełna świadomość służąca oswojeniu podziemia i przyzwyczajenie do komunikacji pionowej, aby pozwolić zaakceptować nowoczesne użycie rezerw przestrzennych podziemia do rozbudowy pełnowartościowej tkanki miejskiej w celu odbarczenia nacisków spowodowanych brakiem przestrzeni użytkowych w miastach.

\section{BEZPIECZEŃSTWO W PODZIEMIU}

Pierwszym prawidłem, które zwraca uwagę projektantów, jest kierunek ewakuacji. Tradycją ludzką jest wznoszenie i piętrzenie budowli, przyzwyczajeni jesteśmy do ucieczki z góry na dół, ku wyjściu na parterze, w przyziemiu, w przeciwnym kierunku niż unoszący się dym z płonącego wieżowca. Z podziemia ucieka się ku górze, razem z unoszącym się dymem. Największymi wrogami podziemnej egzystencji jest ogień i przeludnienie.

Zabezpieczenie pożarowe polega przede wszystkim na zabezpieczeniu dróg ewakuacyjnych przed dymem. W tym celu stosuje się wentylację wysokociśnieniową wysysającą dym na 
zewnątrz, aby ochronić drogi ucieczki. W parkingach podziemnych stosuje się zraszacze automatycznie rozpylające wodną mgłę, gaszącą zarzewie ognia i zabezpieczającą przed jego rozprzestrzenianiem. Wszędzie umieszcza się czujniki wczesnego powiadamiania lokalizujące źródła ognia. Podobnie jak w budynkach wysokościowych w konstrukcjach podziemnych projektuje się sposoby ułatwiające służbom ratowniczym, nie tylko pożarniczym, ale i medycznym, dostęp do poszczególnych partii budynku. Podobnie jak w wieżowcach zabezpiecza się zapas wody.

Podobnie też jak w mallach handlowych naziemnych zabezpiecza się strategię ewakuacji dużej ilości ludzi przebywających równocześnie w tego typu obiektach podziemnych. Jedyną różnicą jest kierunek ewakuacji z dołu do góry, co nierzadko wiąże się z większym wysiłkiem lub fizyczną trudnością. Najważniejszą jednak powinnością dla gospodarza obiektu i samego projektu jest odpowiednie oznakowanie. Jednoznaczna nawigacja, prosty odczyt i łatwe znajdowanie oznaczeń jest podstawą sprawnej akcji ewakuacyjnej. Podstawowym utrudnieniem orientacji jest bowiem niemożność wyjrzenia przez okno, żeby odnaleźć kierunek drogi ewakuacji, a więc niemożność pozycjonowania swojego miejsca na bieżąco.

Dlatego odpowiedzialny za system orientacyjny dla użytkowników projektant Paul Mijksenaar na lotnisku Schiphol w Amsterdamie opracował zasadę "5 C": comprehensiveness, clarity, consistency, conspicuous, catchy - wymagania dotyczące znaków; w tłumaczeniu: zrozumiały, jasny - jednoznaczny, konkretny - bezpośredni, rzucający się w oczy, chwytliwy - przemawiający do wyobraźni. Warto, aby grupy kolorystyczne, np. parami odcieni, wskazywały grupy funkcji, jak na tym lotnisku, gdzie znaki żółte wskazują drogę w kierunku odlotów i przylotów, niebieskie oznaczają miejsca oczekiwania/odpoczynku i restauracje, zielone - drogi ewakuacyjne itd. Oczywiście służby pomocy pasażerom wymagającym opieki analogicznie są potrzebne również w obiektach podziemnych.

Toronto Park and Recreation, kanadyjski wydział organizujący przestrzenie rekreacyjne w stolicy Kanady, opracował nawet przewodnik dla projektantów - listę błędów, które odstręczają użytkowników od przebywania w otwartych przestrzeniach publicznych. Są to: słabe oświetlenie, nieczytelny układ, odizolowanie terenu, wygłuszenie, słaba widoczność, brak dostępu dla służb pomocniczych, miejsca niewidoczne, zanieczyszczenie, wandalizm, obecność włóczęgów. Podobne zasady odnoszą się do przestrzeni podziemnych. Na parkingach pod ziemią często spotykamy np. słupy konstrukcyjne, które zacienione stanowią miejsca niewidoczne. W parkingu podziemnym Laakhaven w Hadze zastosowano więc podpory pochyłe, których kąt pochylenia nie pozwala ukryć się za słupem.

Dbałość o bezpieczeństwo każe np. podwoić tunel w celu segregacji ruchu pieszego i rowerowego od kołowego, monitorować systemem inteligentnym, reagującym na ruch i alarmującym w razie bezruchu osób, zabezpieczać służby gotowe do pomocy użytkownikom w potrzebie, z uprawnieniami dostępu adresów do powiadamiania itd. Osobnym problemem są bezdomni, ponieważ dostęp do usług i prawo wejścia należy się jednakowo wszystkim. Generalnie poczucie bezpieczeństwa wiąże się z obecnością innych ludzi. Miejsca odosobnione budzą respekt niezależnie od obiektywnych wskazań. 
Innym zagadnieniem jest bezpieczeństwo przewodów gazowych lub elektrycznych, które powinny być prowadzone w bezpiecznej odległości od dróg użytkowników, aby zapobiec wybuchom lub przeciekom (przebiciom). Podobnie jest z problemami związanymi z obecnością wody (zalania, podtopienia), w przypadku tuneli (np. metro) nadmiar wody oznacza wypełnienie wodą, a nawet wybicie na powierzchnię w ekstremalnym przypadku. Wszystkie katastrofy podziemne będą mieć wpływ na powiązane miejsca na powierzchni i będą grozić zniszczeniem lub dysfunkcją odnośnych urządzeń naziemnych. Dlatego w planowaniu przestrzennym równolegle z projektem naziemnym i jego zabezpieczeniem musi być prowadzony całościowy projekt bezpieczeństwa i współdziałania trójwymiarowego dla danego terenu.

Najtrudniejszy potencjalny wypadek to zawalenie konstrukcji podziemnej prowadzącej do zruinowania budowli naziemnej i związane z tym pożary lub inne katastrofy.

Trudno też o zabezpieczenie przeciw terroryzmowi, który z założenia wykorzystuje newralgiczne miejsca jako najcelniejsze do ataku - metro w Tokio w 1995 (gaz saarin), metro w Londynie w 2005 (wybuch bomby), metro w Brukseli w 2016 (wybuch bomby). Tego rodzaju niebezpieczeństwo wymaga specjalnych procedur podobnych do tych na lotniskach, przejściach granicznych, bramkach wejściowych na stadiony lub do muzeów itp. szczególnie tam, gdzie nieoznakowany bagaż pozbawiony właściciela wędruje taśmami w kierunku dużych skupisk ludzi lub centrów rozrządu. Nagromadzenie kamer, służb bezpieczeństwa, mundurowych lub uzbrojonych strażników wcale nie poprawia bezpieczeństwa, natomiast wprowadza poczucie stanu zagrożenia, alertu niepotrzebnego w standardowych sytuacjach. Poziom subiektywnego poczucia bezpieczeństwa jest różny dla poszczególnych osób i mieści się w kategoriach psychologii społecznej i własnego stanu psychofizycznej równowagi. Zagrożenia zewnętrzne monitorowane są centralnie.

Podsumowując, przestrzenie podziemne powinny być traktowane jako dopełnienie, rozszerzenie funkcji usługowych naziemnych - ulic, placów, promenad i bulwarów - nie w celu pogrążania ich pod ziemię. Życie miejskie nadal toczyć się ma na powierzchni. W ten sposób można jedynie zyskać większe rezerwy przestrzeni pod powierzchnią i odbarczyć powierzchnię ziemi od uciążliwości, które można ukryć w głębi podziemia. Ulokowane jednak pod ziemią funkcje usługowe nie będą traktowane marginalnie, wręcz odwrotnie, powinny stać się stałym i stabilnym zasobem tkanki urbanistycznej miasta. Nic nie stoi na przeszkodzie, aby zyskały one odpowiednio atrakcyjną oprawę architektoniczną i stały się wizytówką współczesnych miast.

\section{ZARZĄDZANIE PRZESTRZENIĄ PODZIEMNĄ}

Najważniejsze jest zabezpieczenie interesu publicznego użytkowania podziemia. Planowanie przestrzenne musi po pierwsze zgadzać się z globalnymi kierunkami ochrony Ziemi, kolejno wpisywać się w założenia europejskich, narodowych i miejskich planów rozwoju. 
Pierwszeństwo w decyzjach przestrzennych mają względy publiczne, następna w kolejności jest własność prywatna. Wymagany jest pełny serwis geologiczno-urbanistycznych trójwymiarowych informacji cyfrowych, aby jak najprecyzyjniej zaplanować, a zarazem wykluczyć negatywne skutki i potencjalne zagrożenia związane z tymi decyzjami.

W Holandii na przykład działają Holenderskie Korytarze Logistyczne (Dutch Logistic Corridors), których raporty informują o stanie działalności Ministerstwo Infrastruktury i Środowiska. Przynoszą państwu ogromne profity z bezpiecznego i znacznie tańszego nieprzerwanego transportu niebezpiecznych substancji (łącznie z oszczędnością kosztów innego transportu) drogą rurociągów i tuneli. Tym samym oferują zwiększenie bezpieczeństwa ludzi. Pod względem prawnym korytarze należą do sfery prywatnej własności podmiotów gospodarczych, np. dwóch odległych portów wymieniających się transportem dóbr (np. holenderski port w Rotterdamie i belgijski w Antwerpii). Ich prawa prywatnej własności przestrzeni i prowadzenia działalności/użytkowania łączą przepisy dotyczące stref fundamentów (prawo budowlane) i dotyczą zarówno lokalnego strefowania, jak i planowania w skali kraju. Jedyną drogą regulacji jest wywłaszczenie. W obowiązującym prawie tradycyjnie (od czasów rzymskich) własność skrawka ziemi daje w posiadanie wszystko, co jest w jego obrębie, a więc przestrzeń powyżej i poniżej powierzchni. Średniowiecze doprecyzowało ten „słup” własności od jądra Ziemi aż do nieba. Jest więc konieczne wprowadzenie prawa nadrzędności interesu publicznego w stosunku do własności prywatnej do przeprowadzenia przedsięwzięć rangi państwowej i wyższej konieczności. Europejska Konwencja Praw Człowieka (i Podstawowych Wolności) wprowadziła w 8 artykule ${ }^{7}$ uzupełnienie dotyczące prawa własności i jego pozbawienia, które mówi, że musi ono być proporcjonalne i zgodne z obowiązującym prawem demokratycznego społeczeństwa. Pozbawienie własności musi być odpowiednio zrekompensowane.

Dyskusje nad prawem do podziemia są nadal prowadzone, aby ustalony konsensus wszystkich zadowalał. Są bowiem też funkcjonujące od wieków prawa wydobywcze, które pozwalają na wydobycie dóbr podziemnych (kopalnych, paliw, ale też wód termalnych) pożytku narodowego lub publicznego pomimo prawa własności (od $100 \mathrm{~m}$ w głąb dla kopalni i ponad $500 \mathrm{~m}$ dla geotermii). Uprawnienia zdobywane są drogą negocjacji. Prawo anglo-amerykańskie określa kilka kategorii serwitutów w prawie cywilnym różniących się w obrębach różnych krajów. Dla projektów międzynarodowych, o dużym zasięgu, negocjacje mogą wymagać pokonywania karkołomnych trudności związanych z różnicami prawa w każdym kraju - każdego z zainteresowanych kontrahentów.

Przykładem może być szwajcarski CERN, gdzie powstał Wielki Zderzacz Hadronów, stworzenie którego wymagało dokumentów opierających się na tamtejszym prawie określającym własność terenu do głębokości warstwy ekonomicznej/użytkowej. Poszczególne kantony regulują indywidualnie te wartości, więc już obecnie, dla dobra publicznych przedsięwzięć, regulacje nie pozwalają na dowolność interpretacji prawa.

Przykładowy konflikt interesów budowy podziemnego miasta w Montrealu z własnością warstwy podziemnych sieci miejskich wskazuje na zależność ukształtowania zabudowy 
miasta na powierzchni od problemów własności podziemia. Podobna sytuacja miała miejsce w Japonii, która zawsze narzucała limity własności ze względu na ograniczenia obszarowe - spowodowało to wprowadzenie limitu głębokości własności terenu określonej na 40 m poniżej piwnic i 10 m poniżej stóp filarów konstrukcyjnych. Głębokość poniżej wyznaczonej leży w gestii własności państwowej.

W 2015 roku parlament Singapuru wydał dwie poprawki do uregulowań prawnych dotyczących podziemia, co umożliwia wykorzystanie go dla dobra ogółu. Są to: nowe prawo do nabywania gruntów i nowe prawo gruntowe, które opisują własność terenu wyłącznie do głębokości potrzebnej do satysfakcjonującego użycia - w uzasadnionych przypadkach maksymalnie do $30 \mathrm{~m}$ w głąb terenu.

Bez wątpienia problematyka uregulowań prawnych dotyczących przestrzeni podziemia musi dostosować obowiązki uwzględniające różnice fizjograficzne i prawne różnych krajów interesariuszy porozumień międzynarodowych. W gospodarce globalnej wymaganie światowego konsensusu prawnego wspólnego dla wszystkich jest nieodzowne. Musi być jednak poprzedzone uregulowaniem sytuacji prawnej w każdym z państw członków układu.

Rysują się również pytania o przyszłe możliwości rozwoju sieci przestrzeni podziemnych i ich późniejszych możliwości dostępu do powierzchni terenu.

1. Czy budowanie ponad powstałym tunelem jest legalne i fizycznie możliwe?

2. Czy tunele i ich służebne urządzenia będą limitować skalę i intensywność przyszłej zabudowy naziemnej?

3. Czy koszty użytkowania wzrosną dla terenów z tunelami podziemnymi?

4. Czy ograniczenia na terenach podziemnych parkingów wpłyną na koszty i możliwości budowy oraz użytkowania?

Podziemne inwestycje uwzględniać muszą różnice wynikające z samego podłoża geologicznego. Skalisty grunt umożliwia najtańsze i najbardziej stabilne prowadzenie tuneli przy najmniejszym wpływie na decyzje późniejsze. Grunty bardziej miękkie, plastyczne i poddające się działaniu morfologicznemu wymagają większej ilości zabezpieczeń. Trudniej też przewidzieć wszystkie możliwe utrudnienia wynikające z przyszłych zmian. Trudniej więc zabezpieczyć je również prawem własności.

Nie ma jednakowych warunków do prowadzenia tunelu w różnych miejscach świata, nie ma jednakowego dla tego prawa. Jedne i drugie warunki różnią się w zależności od rodzaju terenu i strefy klimatycznej, również od podziałów geograficznych, politycznych i samej polityki danego państwa. Główne podziały systemów prawnych to anglo-amerykański i europejski z kodyfikacją francuską (napoleońską), ale większość sporów i wątpliwości interpretacyjnych wyjaśniają sądy. Ważne jest sformułowanie prawa deliktowego dotyczącego podziemia, aby odpowiednio formułować kontrakty i umowy skutkujące przyszłymi możliwościami użytkowników.

Istotne dla miejscowych rozwiązań są różnice postrzegania zasobów podziemia ze względów klimatycznych. Dla bieguna ciepła w Australii podziemie jawi się najbardziej luksusowym 
miejscem do życia z przyjemną temperaturą i ciszą dającą pełny relaks. Dla Greków z kolei wykorzystanie podziemia jest wyjątkowo ograniczone nawarstwieniem archeologicznych pozostałości kulturowych ważkich w skali całej cywilizacji.

Im większy jest przyrost podziemnych rozwiązań miejskich, tym ważniejsza jest zrozumiała dla wszystkich kodyfikacja przestrzeni podziemnych, zunifikowana globalnie, aby sposób użytkowania stał się naturalny dla każdego. Użytkowanie podziemia niesie ograniczenia w stosunku do analogicznych przestrzeni naziemnych w postaci problemów wyjścia na powierzchnię, braku naturalnej orientacji (strony świata), dużych dystansów podróżnych, słabej wentylacji, trudności komunikacyjnych, innego niż tradycyjny przebiegu alarmu pożarowego. Stąd potrzebna jest stała aktualizacja kryteriów w zakresie: zaleceń konstrukcyjnych, umożliwiania wyjścia/ucieczki, kontroli i alarmowania przeciwpożarowego, systemów supresyjnych, przygotowania ratunkowego, dodatkowych służb pożarniczych.

\section{OPŁACALNOŚĆ INWESTYCJI PODZIEMNYCH}

Nie ma wątpliwości, że rezerwy przestrzeni oferowanych przez podziemie będą wykorzystywane. Odkrywają one możliwości rozwiązań wielu nękających miasta problemów urbanistycznych, komunikacyjnych, strategicznych i socjalnych, dają sposobność ułatwień codziennego życia, dywersyfikacji usług, optymalizacji funkcjonalnej, modernizacji i unowocześnienia obsługi miasta, a przede wszystkim zlikwidowania dominacji ruchu kołowego i przywrócenia równowagi biologicznej na powierzchni Ziemi. Największym jednak niebezpieczeństwem związanym z zagospodarowaniem i eksploatacją przestrzeni podziemnych jest naruszenie równowagi biosystemów podziemnych. Nie jesteśmy w stanie przewidzieć wszystkich dalekosiężnych skutków naszej eksploracji. Tak jak urbanizując powierzchnię przed wiekami, ludzkość nie wybiegała wystarczająco daleko w przyszłość, nie przewidywaliśmy takiego przyrostu naturalnego, nie spodziewaliśmy się tak daleko idących skutków działalności człowieka, dewastacji ekosystemów przyrodniczych, zatrucia wód, naruszenia naturalnej gospodarki wodnej, redukcji gatunków żyjącej fauny i flory, wyniszczenia całych obszarów uprawnych, dewastacji zwartych zasobów zieleni, odnawiających się kiedyś samorzutnie, w końcu zatrucia powietrza, którym na co dzień oddychamy, a którym obecnie się dusimy.

Te wszystkie fragmentaryczne szkody skupiły się najintensywniej w miastach, tworząc wyspy ciepła, i synergizujące się do efektu podgrzania atmosfery skutki: zanieczyszczenia gleby toksycznymi substancjami, nie dające się zlikwidować zaśmiecenie, w tym skażenie toksycznymi odpadami, a w tym zaśmiecenie sztucznym oświetleniem - czyli rozjaśnienie nocnego nieba niezbędnego do prawidłowego życia biologicznego. Nakładające się inne pojedyncze akcje urbanizacyjne oraz planowo prowadzone przez dziesięciolecia dewastacje przyrody podejmowane dla jak najpełniejszego uprzemysłowienia gospodarek dały w efekcie nieodwracalne 
zniszczenia, a w tym globalną zmianę klimatu wokół Ziemi. To nie jest tylko podniesienie średniej temperatury rocznej w Europie Środkowej, gdzie co najwyżej zmniejszyła się uciążliwość zimy i wydłużyły „letnie wakacje”. Cierpi na tym cała przyroda, ale i my sami odczuwamy skutki w postaci chorób cywilizacyjnych, nowych postaci tych chorób, ogólnego osłabienia odporności, mutowania się genów, biodegradacji gatunku ludzkiego (spadek urodzeń, trudności rozrodcze, kalectwa wrodzone, choroby genetyczne, nadwrażliwość i zmiany psychiczne). W podobny, choć niezawiniony sposób okaleczana jest cała fauna i flora, a w konsekwencji łańcucha zależności - my sami z powodu zainicjowania tych zmian.

Z konieczności ratowania tego, co zostało jeszcze niewyniszczone, z konieczności powstrzymania bezmyślnej i beztroskiej ekspansji oraz w trosce o własną przyszłość i przyszłość bliskich - w osobach potomnych - nie ma odwrotu od jednomyślnego globalnego opamiętania i sukcesywnego niwelowania i odwracania strat. Wystarczy wspólna i jednostkowa pełna świadomość i odpowiedzialność.

\section{PRZYPISY}

1 H. Brown, Next Generation Infrastructure. Principles for Post-Industrial Public Works, Island Press, New York 2014.

2 W. Broere, Urban underground space. Solving the problems of today's cities, „Tunneling and Underground Space Technology", 55/2016, 245-248.

3 M. Hajer, T. Dassen, Smart about Cities. Visualising the Challenge for $21^{\text {st }}$ Century Urbanism, PBL Netherlands Environmental Assessment Agency, Rotterdam 2014.

4 Rethinking the Clyde Waterfront, YPTDP, ISOCARP+itacus+TDUK, UK, Glasgow 2016.

5 M. Bloomberg, C. Pope, Climate of Hope. How Cities, Businesses, and Citizens Can Save the Planet, St. Martin's Press, New York 2017.

6 R. Sterling, N. Bobylev, Urban underground space. A growing imperative: Perspectives and current research in planning and design for underground space use, "Tunneling and Underground Space Technology", 55/2016, 1-4.

7 Art. 8 Konwencji Europejskiej dotyczy poszanowania życia prywatnego i rodzinnego.

\section{BIBLIOGRAFIA}

Admiraal H., Cornaro A., Underground Spaces Unveiled. Planning and creating the cities of the future, ICE Publishing, Londyn 2018.

Bèlanger P., Landscape as Infrastructure, Routledge 2016.

Bloomberg M., Pope C., Climate of Hope. How Cities, Businesses, and Citizens Can Save the Planet, St. Martin's Press, New York 2017. 
Broere W., Urban underground space. Solving the problems of today's cities, „Tunneling and Underground Space Technology", 55/2016, 245-248.

Brown H., Next Generation Infrastructure. Principles for Post-Industrial Public Works, Island Press, New York 2014.

Hajer M., Dassen T., Smart about Cities. Visualising the Challenge for $21^{\text {st }}$ Century Urbanism, PBL Netherlands Environmental Assessment Agency, Rotterdam 2014.

New Urban Agenda (NUA), 2017, UN, Equador, The United Nations publication, Habitat III Secretariat, A/RES/71/256*.

Rethinking the Clyde Waterfront, YPTDP, ISOCARP+itacus+TDUK, UK, Glasgow 2016.

Shanghai Manual. A Guide for Sustainable Urban Development of the $21^{\text {st }}$ Century, United Nations Department of Economic and Social Affairs (UNDESA), 2012, [online] sustainabledevelopment.un.org (dostęp: 15.11.2019).

Sterling R., Bobylev N., Urban underground space. A growing imperative: Perspectives and current research in planning and design for underground space use, „Tunneling and Underground Space Technology", 55/2016, 1-4. 